\title{
LITERARY, METHODOLOGICAL PARADIGMS: THE THEME OF ARTSAKH IN THE WORKS BY RAFFI AND MURATSAN
}

\begin{abstract}
The works "Khamsa Melikdoms" by Raffi and "Baghtasar Metropolitan Hasan-Jalaliants Brief Biography", "Ruzan or the Patriotic Girl" by Muratsan and their comprehensive research and re-evaluation are the chapters of "Artsakh in the Armenian Literature of the XIX century" research and the primary data for the article given.

In the research, the subject of Artsakh is presented within the general framework of Armenian literature of the XIX century as a literary phenomenon viewed separately.

It has its traditional layers and unique documents of secular culture and art, literary, political, philosophical thought.
\end{abstract}

Keywords: Artsakh history, mentioning, Jalal Ishkhan, Varanda, sublime mountains, monastery.

Introduction

The past literary traditions continued with the spirit of restoration in the XIX century, opening the arena for the new literary names emphasizing the national ideology, such as M. Taghiadyan, S. Archbishop Jalaliants, Gh. Alishan, A. Kostandyan, Raffi, Muratsan, Leo, Haykuni, M. Barkhudaryan.

\section{General Characteristics of the Work}

The works "Khamsa melikdoms" by Raffi and "Baghtasar Metropolitan Hasan-Jalaliants Brief Biography", "Ruzan or the Patriotic Girl" by Muratsan with their literary and methodological fundamental research and re-evaluation are the main chapters of research under the title "Artsakh in the Armenian Literature of the XIX Century", partial reference to which is the analysis of the works by Raffi and Muratsan presented in the given scientific article.

Collectively, the subject of research in "Artsakh in the Armenian Literature of the XIX Cen- tury" and the works by Raffi and Muratsan being a part of it is the history of the literature created about Artsakh.

\section{Topicality}

In general, the research of the works "Khamsa Melikdoms" by Raffi and "Baghtasar Metropolitan Hasan-Jalaliants Brief Biography”, "Ruzan or the Patriotic Girl" by Muratsan is the first literary and methodological attempt of identifying, interpreting and evaluating against the general background of the Armenian literature of the XIX century one of the central themes - the theme of Artsakh of the XVII-XIX centuries in the general context of the book events, which, according to the sharpness of the political issues presented by it in the modern era, answers the fabrications of would-be scientists who distort the history of Artsakh. It acquires an actual sound with exceptional political, ideological, philosophical, methodological, aesthetic, moral and psychological problems.

The scope of the topic is quite broad, so we preferred those key monuments that artistically 
and typically represent the literature and history of Artsakh, the natural and geographical picture.

Subject, Purpose and Task of the Research

The primary purpose and task of the scientific research is the characterization and evaluation, re-evaluation of the literature of Artsakh in the thematic, ideological and stylistic, literary, methodological space, the works of Raffi and $\mathrm{Mu}-$ ratsan in particular.

The typological features indicating the authors' - Raffi ("Khamsa Melikdoms") and Muratsan ("Baghtasar Metropolitan Hasan-Jalaliants Brief Biography", "Ruzan or the Patriot Girl") unifies the thread that generalizes the theme of Artsakh, which reveals the spirals, patterns, original and fruitful manifestations of the development of the history of this Armenian region, layers of re-evaluation.

\section{Research and Scientific \\ Novelty of the Topic}

It is true that both in the study "Artsakh in the Armenian literature of the XIX century" and in the article presented for analysis and re-evaluation, the works of Raffi and Muratsan were subjected to a certain consideration by literary critics (Leo, A. Terteryan, S. Sarinyan and others), but did not receive a fundamental theoretical assessment and, in certain cases, in epic and genre, methodological issues. The scientific innovation of the work is that attempts are made to subject the works of Raffi ("Khamsa Melikdoms") and Muratsan ("Baghtasar Metropolitan Hasan-Jalaliants Brief Biography", "Ruzan or the Patriot Girl") to literary and methodological research and re-evaluation, what the given work is aimed at.

\section{Methodology}

When writing the article, we used comparative, contrasting, source studies, analytical, struc- tural, re-evaluation, metrological methods.

\section{Research}

The method has a double meaning in terms of aesthetics: scientific, literary and artistic. In this case, the creative literary method is identified with the romanticism, realism, symbolism, futurism of literary directions, currents. At the same time, the method outlines directions in literature historical, biographical, cultural-historical, etc.

Historicity became the revelation of time. "The $19^{\text {th }}$ century was a century of history - general (civil) history, literature art history, language history of mythology, philosophy of science and history of religion, history of economics, history of state and legal laws" (Gaydenko, 2000, p. 385).

The $19^{\text {th }}$ century marked a new step in the development of literary methods.

The independent path in life is chosen by original literary methods, such as biographical, historical, mythological.

The biographical method is recognized as the first method of literary studies. The method's founder is the French literary critic Charles Auguste de Saint-Beauvoir, who is best known for his two-volume work "Portraits" (1836-1839).

The descendants of Saint-Beauvoir were George Brandes, Hip. Ten etc.

The biographical method has become dominant in Armenian literature since the 70 s of the $19^{\text {th }}$ century, the examples of which are Muratsan (Grigor Ter-Hovhannisyan), "Baghtasar Metropolitan Hasan-Jalaliants Brief Biography", Shahnazaryan "The case of Khachatur Abovyan's literature", N. Ter-Karapetyan "Khachatur Abovyan", E. Shahaziz "Mikayel GhazaryanNalbandyants", A. Yeritsyan "Grigor Artsruni", I. Harutyunyan "Stepanos Palasanyan", A. Chopanyan "Petros Duryan's biographical, critical study" works, etc.

The methodological analysis of Muratsan's (Grigor Ter-Hovhannisyan) "Baghtasar Metropolitan Hasan-Jalaliants Brief Biography" is the 
first part of the third chapter of the general scientific study "Artsakh in the $19^{\text {th }}$-century Armenian literature".

The work was written on the principles of the biographical method, which was the first method in European literature (the method was founded by the French literary critic Auguste de SaintBeauvois in his "Portraits" (1836-39). The biographical method lasted until the late $19^{\text {th }}$ and early $20^{\text {th }}$ centuries).

The short biography "Baghtasar Metropolitan Hasan-Jalaleants Biography” by the great Armenian classic Muratsan (Grigor Ter-Hovhannisyan, 1854-1908) is historicity mixed with fiction, revolved around a Supreme Pontific of Artsakh Metropolitan Hasan-Jalaleants. He lived and served as the pastor of earthly "multifarious" (Muratsan) life in 1775. January 12, till 1854 July, 27. He was honoured by his compatriots and even enemies during his lifetime on July 27 , 1918, and was considered a saint.

The biography, signed by Grigor Ter Hovhannisyants, was written by Muratsan in 1877 . The author originally published it in 1880 . In the $5^{\text {th }}$ issue of "Pordz" magazine, which was summarized on pages 132-164. It consists of a small entrance and A-E parts.

By its nature and methodology, however, this biography of Muratsan is not limited to the family of Metropolitan Hasan-Jalalyants, Baghdasar and his biographical information.

The image of the spiritual leader the author summarized in parallel with the revealing of the historical and political image of the Artsakh world and its heavy but heroic and full of struggle fate.

Grigor Ter-Hovhannisyan, using his idea, highlights the questions that bother him.

a. "Artsakh, which is equal to the other states of

Armenia, has sometimes suffered more from the devastation of the enemy beasts and so far has received very little attention from our archaeologists."

Muratsan toured the historical territories of Artsakh and Syunik with the aim of getting ac- quainted with the native memories. Muratsan mentions the following about this in his "Autobiography". "I spent most of 1877 touring different parts of my native country, studying the ruins of Artsakh, Syunik and old monuments. After returning from this tour, at the end of 1877 , I wrote my first very small and very large piece in (Shushi), which was the brief genealogy of the Hasan-Jalalyan family, the biography of that family, the last heir of the Catholicosate from Aghvan, Metropolitan Hasan-Jalalyan (Muratsan, 1963, p. 136).

The author concluded that Artsakh was more subject to the barbarities of the enemies than Armenia. from here:

b. "Many Artsakh monasteries, impregnable castles, hard-to-reach people, after all, every mountain and field, forest and gorge have memorable holes worth capturing".

c. "But a lot will be lost if our compatriots are still careless in researching all this, let them disappear under the fast current of time".

Muratsan highly appreciates those who bravely fought against the enemy for centuries.

d. "These were the offspring of the great dynasties that arose from the remnants of the old knightdoms, which lasted until the beginning of the century" (Pordz, 1880, p. 131).

In the foreword to his essay, the author emphasizes the "original purpose" of the article, which is that after briefly tracing the origins of the Hassan-Jalalian dynasty, which is famous in the Artsakh clans, let us turn to the biography of the worthy Baghdasar Metropolitan descended from this dynasty, by which we will partially repay the gratitude of Shushi inhabitants, who was greatly benefited from this worthy person (Pordz, 1880, p. 132).

In Part A of the historical review, Muratsan considers the Jalalyan ruling dynasty to be the oldest dynasty in Artsakh and Syunik, coming to modern times, with a chronology of more than a thousand years. Its origin is connected with the knight-royal dynasty of the Bagratuni, "...the son of Smbat the Confessor and Prince Sahl, 
brother of Ashot I" (Pordz, 1880, p. 132).

Noting the glorious activities of the prince and the description of branches of their dynasties, he highlights the history of the foundation of the Hasan-Jalalyan dynasty.

...Born by the prince Vakhtang B and lady Khorishah, the Great Hasan-Jalal-Tolai after whom his descendants were named Hasan-Jalalian, Zakaria, Ivaneh, Dolly, their sister Mariam.

Hasan-Jalal was educated under the tutelage of his pious parents, growing up and taking over his power after his father's death (Pordz, 1880, p. 138).

The ending of Part A has the following message, which represents the core of the material. "The Jalalian dynasty, in addition to prominent princes, granted the nation Catholicos, who ousted the Catholicosate from Aghvan for a long time, especially when the seat was moved to Gandzasar. Among those Catholicos were Hovhannes A., Matthevos, Simeon, Aristakes, Sarkis A., Grigor, Jeremiah, and Isaiah (the Catholicos of Isaiah, who died in 1728, wrote a brief history of his modern-day Georgian journey from Aghvan, 1839, published by the Metropolitan Baghdasar in Shushi), Hovhannes B., Sarkis B., during which the Catholicosate was taken from Aghvan.

From this dynasty came many priests, vardapets and bishops, among whom Metropolitan Baghdasar Hasan-Jalaliants, the first diocesan leader of Shushi, was blessed for his national deeds and whose brief biography we present to the reader (Pordz, 1880, p. 142).

Baghdasar Metropolitan was one of the two sons of Prince Daniel and lady Hripsimeh. Prince Daniel was one of eight sons of Prince Melik Bey, who was the eldest of the Jalalian dynasty in Artsakh in the 1700s. "Baghdasar was born in Gandzasar, Khacheno, on January 12, 1775. He was baptized in the magnificent monastery of Gandzasar by the hand of Bishop Athanas of Topeants, and had a godfather, Bishop Hagop".
Gandzasar was a place of the enjoyable baptistery, intellectual, thoughtful courage at the same time for Baghdasar. His teacher was his uncle Archbishop Sargis.

Muratsan lists the atrocities of Ibrahim, the so-called khan of Karabakh, against the spirituality, meliks of Artsakh and the people, who could not escape the latter's illegalities anymore and wrote a petition to Empress Catherine to support them in 1785 .

Along with the political description of Artsakh, Muratsan also comments on the details of Baghdasar's future, Ibrahim's assassination, and the migrants' petitions to return to Karabakh. Part $\mathrm{C}$ of the biography presents the improvements of the returnees, especially Baghdasar, in order to eliminate Gandzasar's pure condition and restore it to its former glory.

In the biography, Muratsan mentions the end of the Catholicosate from Aghvan in 1815, which lasted 1736 years and ended with the Jalalyan dynasty.

Archbishop Sarkis, with the intention to make Baghdasar the receiver after himself, sent him to Etchmiadzin, where at the age of 45, on September 18, 1820, he was ordained a bishop by Catholicos Ephrem.

In Part D of the historical review, Muratsan presents Baghdasar as a selfless and devoted example of a spiritual leader who has endured many troubles but with courage. On September 18, 1830, at the request of the people of Artsakh's meliks, Baghdasar was sent to Etchmiadzin and ordained by Catholicos Yeprem as a Metropolitan from Aghvan.

At the end of part D, Muratsan lists the daring and courageous undertakings of Metropolitan Baghdasar in 4 years, which aroused everyone's admiration and surprise. For the benefit of these services, through the mediation of the Catholicos, he was awarded by Emperor Nicholas I the Order of St. Anne of the First Degree.

In 1836 with the confirmation of the consistories, Catholicos Hovhannes Karbetsi appointed 
Metropolitan Baghdasar as the state leader of the state of Artsakh.

In 1838 the diocesan school of Shushi opened with 20 students in the first year. The school gained a ticket to long social life with its educational, methodological, cultural and public life through its further activities, being guided with the school principles of Hovsep Artsakhetsi. In 19366 dioceses were established in the RussianArmenian region with the adoption of "Polozheni" on March 11, 2006. The Karabakh Diocese included the provinces of Karabakh, Shaki and Talish. Shushi was considered the cultural and enlightening centre of the Karabakh Diocese.

Metropolitan Baghdasar conducted trials against Mehti Khan's still-powerful daughter Natavan other beys and gained them, "gaining the vast lands that occupy as much space as Artsakh" (Pordz, 1880, p. 159).

Muratsan also enumerates the services of a high-ranking spiritual figure in the field of education.

This huge activity brought the multi-deserved, multi-talented figure closer to his earthly end on June 27, 1854.

For eight days, there were disputes over where to bury his body, in Shushi, where his coffin was passed through all the churches, or in Gandzasar. Finally, according to the will accepted by the pope, his body was taken to Gandzasar with a big ceremony and buried in the magnificent vestibule of his cousin's Jalalyants government cemetery, in the magnificent vestibule of Gandzasar monastery, next to the tombs of his uncles, Catholicos Hovhannes, Metropolitan Sargis.

B. Ulubabyan mentions the patriot's funeral: "The funeral turned into a pan-Artsakh mourning ceremony. It is said that one end of the mourning procession was in Shushi, the centre of his grateful activity, and the other end was in Gandzasar, the last resting place of himself and the glorious elders of his family" (Ulubabyan, 1994, p. 189).
The behaviour of Metropolitan Baghdasar reminds M. Mashtots' multifaceted activities led in favour of national ideology.

Hagiography as a genre found its formation and spread after the victory of Christianity in Byzantium in the IV century. It became widespread in the Armenian Middle Ages.

Armenian behaviour, as a methodological specificity, is characterized by historicity. They were written about spiritual and worldly persons canonized by the Christian Church.

Historical nature as a methodological feature is typical for Armenian Hagiography. They are written about spiritual people who are considered saints by the Christian Church and secular persons.

The historical method is considered one of the leaders in the analytical methods of modern Armenian literature.

The emergence of the historical method (originated in the early $19^{\text {th }}$ century) is marked by the fact that history breaks away from the theological mould and acquires cultural, civilized, social content. The statements of Schelling, Buckley, Herder, etc., transform the perceptions the ideas about history. History acquires a methodological principle for the sciences.

According to the historical method, literature is considered as history. It becomes applicable in the historiography of literature.

The formula of the historical method is absolutely true. "As the history of a nation is, so is its literature".

The representatives of the historical method in Armenian literature were Stepanos Nazaryan, Garegin Zarbhanalanyan, Hovsep Gatrchyan.

Impressionism (French - impression) originated in France (late $19^{\text {th }}$ century - early $20^{\text {th }}$ century). It found its expression in Art and Painting. Impressionism is a trend in world literature and art.

The expression of Impressionism is a subjective perception of the objective image. 
The features of impressionism found their expression in the poetics of naturalism (E. Zola), symbolism (Verlaine, M. Maeterlinck).

The methodological and aesthetic analysis of the drama "Ruzan or the Patriot Girl" by Muratsan is the second part of the third chapter of the general scientific study "Artsakh in the Armenian literature of the $19^{\text {th }}$ century", which requires a complete re-evaluation of the methodology and literary trends (Symbolism, Classicism, Romanticism), which is what the work is dedicated to.

The founder of the psychological school in the history of Armenian literary studies, the great literary critic A. Terteryan, wrote a literary and methodological study of the historical and patriotic drama "Ruzan or the patriot Girl" by $\mathrm{Mu}-$ ratsan, which the literary critic published in a general study entitled "Muratsan as a thinker and aesthetician" in 1913. The material of the drama is taken from the Mongol-Tatar invasions $\left(13^{\text {th }}\right.$ century, the original source of K. G. Gandzaketsi - "History of Armenia").

Ruzan's father Hassan Jalal is the great patriot of Khachen, who, after the Mongol-Tatar invasions of 1238-1239, began the construction of the miracle of medieval art of Artsakh - Gandzasar and completed it; he also carried out its opening with the participation of spiritual leaders.

The bearer of the rich traditions of the princely house of Asan-Jalalyan Khachen is also Ruzan, who sacrifices her personal happiness for the sake of saving the Motherland.

The founder of the psychological school in Armenian literary studies compares Muratsan's drama "Ruzan" with "Monna Vanna", the work of one of the greatest figures of Belgian literature of the late 19 th and early $20^{\text {th }}$ centuries, playwright, poet, theorist of the literary school of symbolism, mystic Maurice Maeterlinck (18621949). The drama was published in 1902.

The latter, overcoming the impulses of the literary direction of symbolism, contributes to the foundation of romantic and realistic drama in
Belgium. "Princess Malen" brought him great success, putting his name on a par with Shakespeare.

Maeterlinck's plays "The Uninvited" and "The Blind" were recognized by theorists as classic examples of the "theatre of grief and expectation".

"In order to convey something to each other, it is necessary to be silent" - this advice is the essence of Maeterlinck's aesthetics. It undoubtedly delivers something on the example of "Monna Vanna", between which and "Ruzan", A. Terteryan outlined the edges of comparison to the detriment of the latter. Why ... But what similarity there is between Monna Vanna and Ruzan in terms of artistic elaboration and psychological truth. Monna Vanna is the perfect woman, and her femininity is not natural only but also necessary. When Monna Vanna first hears the enemy's offer to go to his tent one night, provided the siege is lifted, she says nothing, silent and complaining..." She didn't answer. She complained and left without saying a word (Terteryan, 1913, p. 13).

Ruzan: "I... that spent sleepless nights at the beds of the sick ... today I must be the cause of blood and curses ...Oh, no..." if a sacrifice is needed, then let them sacrifice me, let them send me to the enemy, let them betray me to the Tatar ... if only the pain would disappear from the people.... (v. II, p. 81) Why should two heroines act in the same way in the same circumstances: this is ridiculous. And then, the circumstances in which the heroines act, and the reasons, and their proposals, conditions, historical, political, epic forms of the enemy are completely different ... the propensity and credo of the writers who romanize them are different as well, from the point of view of belonging to one or another literary school.

A. Terteryan's conclusions are unconvincing. After a short speech, Monna Vanna leaves, and the reader or viewer experiences her inner suffering alone. She's not happy, which means she's upset. So, if the heroine is silent, then she is natu- 
ral, and ... Ruzan is not like that. She cannot excite the viewer. This is the wrong method of negation. "We do not believe the verbosity of $\mathrm{Mu}$ ratsan and his heroine because they both solve the issue easily, without any tragedy. For the first time, Ruzan comes to us with her ready-made solution, but we believe that this decision is not so easy to make..." (Terteryan, 1913, p. 136).

By the way, we note that the symbolists believed that the artistic picture should only be guessed and not understood and talked about a lot. Nor does the circumstance of Monna Vanna's silence proceed from this ... after all, Maeterlinck was also considered a theorist of symbolism ... and sometimes the one who accept its principles and follow them.

For Terteryan, the quarrel between Vanna and her husband - to go to the enemy army - is more convincing than the quarrel between Ruzan and her father - not to give in to the enemy. "Maeterlinck has created a beautiful determination without justification or excuse. Muratsan had a boring argument between father and daughter. And we feel more for Mona than for Ruzan, who makes very clever judgments. And another layer of conclusion that is unfair. "This", Terteryan continues, "leaves a repulsive impression after meaningful speeches. Monna's husband approaches and demands an explanation, but she refuses: "No..., No", Monna avoids, "I can't... If I say a word, all my strength will perish ... I love you, but I still have to go..." (Terteryan, 1913, p. 136).

No, it is by no means possible to compare two heroines in such literary forms.

Hence their originality, a characteristic feature of temperament is.

The literary critic, speaking about the last episode of Monna's performance and what prompted her to take this step, quotes her as saying: "That people are dying of hunger..." (Terteryan, 1913, p. 138).

In relation to "Ruzan", Terteryan states his last, undoubtedly unconvincing word. "In general, "Ruzan" as a drama is a very weak work"
(Terteryan, 1913, p. 138).

From the point of view of the literary direction of symbolism, Terteryan (2009) evaluates "Ruzan", which bears abundant elements of classicism and romanticism, creating a contrast with "Monna Vanna", which has elements of symbolism.

Undoubtedly, we believe that the dramas "Monna Vanna" and "Ruzan" belonging to different literary methods and directions should not have been compared.

The secret of longevity is in the revelation and manifestation of "Ruzan's" great advice, the idea of self-sacrifice for the sake of patriotism, the burnt offering of the rich spiritual charges and powerful heroine Ruzan.

"Thus, it should be logically stated that these shortcomings were the reason for the longevity of "Ruzan".

"If this is true, Muratsan continues, then, indeed, an amazing people are the Armenians, who live in themselves only bad writings for a long time. Based on this, the rest of our historical plays also had to live for a long time, but why did they die?" (Muratsan, 1954, pp. 377-378). Let's assume that Muratsan's words also refer to A. Terteryan's comments and methodological questions.

Turning to "Monna Vanna", we note that the significance of the issue of saving Monna Vanna was social, and Ruzan - political, liberal.

When asked by the enemy commander what had forced Monna to surrender to him, she replied briefly and sharply: "That people are dying of hunger..." (Terteryan, 1913, p. 36).

Small Belgium had great calamities and enemies as well, but the Armenian country had more and more of them: however, Ruzan and her ideological tirade were different, especially on the stage. Furthermore, today, as a whole nation, we listen to the great advice of "Ruzan", and to the annual Muratsan Art Days, which became permanent in Shushi before the war, when Ruzan honoured the living, and ... her march, indeed, has continued and will continue for centuries, 
like heroic Artsakh itself.

Indeed, neither Leon, nor A. Terteryan, nor others, based on the principles and methods put forward by them, correctly evaluated "Ruzan" both in terms of genre and gender, methodology, and related literary direction, and in terms of interpretation of the criteria for the examination of this time period.

Based on all this, we prove that the drama "Ruzan" requires a new methodology, a re-evaluation with the definition of criteria for literary values, which became the object of our research.

Semiological method. Semiology (semiotics) a method based on structural positions.

Semantics (Greek. Semeion-sign) studies sign systems, their properties, signs, their nature and types.

The founders of semiotics are French linguist F. Saussure (1857-1913) and Sh. S. Pierce (USA, 1839-1914).

In the Course of General Linguistics, Saussure notes that the most important of all systems is the sign system. The critic discovers that among the "other systems" of the language system, there are generalizing terms that can be used to characterize other sign systems in the language.

The study of Raffi's novel "Khamsa Melikdoms" is the second part of the first chapter of the general scientific study "Artsakh in the Armenian literature of the $19^{\text {th }}$ century", which possesses methodically theoretical components both of historical, and symbolic methods.

Genres in their concrete manifestations represent the unity of traditional and modern. This phenomenon is best characterized by Bakhtin (1963): “...The antiquity that persists in the genre is not dead, but the eternal living, that is, the antiquity that is capable of renewal. The genre lives in the present but always remembers its past and beginning. Genre is a representative of creative memory in the process of literary development. That is why the genre is able to ensure the unity and continuity of this development" (pp. 141142).
Raffi, calling "Khamsa Melikdoms" a historical study, still considers it a value of literature. Let's try to reveal the trend with the author's underscores.

Using the symbolic method, we also explored the "Khamsa Melikdoms" in the literary field.

In the article "Novel-writing of Russian Armenians", published after the writer's death, Raffi, expressing dissatisfaction with the society's untruthful assessment, notes: “...In our literary sphere, we acted both as a publicist and as a writer... We will present a small score only in our epic (italics by Z. B.) achievements" (Raffi, 1959b, p. 160).

Raffi highlights his method and states that no writer before him paid attention to the past. Indeed, he was one of the first to enter the depths of history and bring to light the heroes of ancient Armenian times, writing the novels "Davit Bek", "Paruyr Haykazn", "Samvel", then translated the novella "The Karabakh astrophysicist" by Pl. Zubov, emphasizing the importance of the role of literature among modern art forms.

The author writes about this, including "Khamsa Melikdoms" in his epic work. "Before us, the history of Armenia began with Hayk" and ended with Leon Z. We were the first to find the lost Armenian power in obscurity when we wrote "Khamsa Melikdoms" (Raffi, 1959a, p. 161).

Raffi emphasizes that he did not have a predecessor; he was followed by new Armenian writers. He was the first who dared to turn the still raw, poor literary language of Armenia into the novel's language, preserving his independence in his works.

The author presents himself as the ideological mastermind of a new literary direction (italics by Z. B.).

Considering "Khamsa Melikdoms" the "crowning glory" of his work, presenting it as a "historical study", the aesthetician at the end of the book, speaking about the principle of division of labour, methodological questioning, at the same time mentions an important circum- 
stance that orients the genre. "I would consider myself happy if I could do a small service to our literature in this endeavour (italics by Z. B.) (Raffi, 1959a, p. 395).

Thus, writing "Khamsa Melikdoms", Raffi considers his mission not in historiography but in literature. We can show this trend in other examples (italics by Z. B.).

Writer Raffi brings the story of a lost, forgotten power from the dark to light, spending his heaviest material resources. And so that there is no reason to doubt that the "Khamsa Melikdoms" is a product of the author's imagination (italics by Z. B.), for this purpose, in the conclusion of our book (pp. 369-414), we have printed one by one the names of all the sources, up to their content, which we used in compiling our history" (Raffi, 1959a, p. 148).

Based on these concerns, the author considered the work created for literature as a historical study, especially since at that time in literary studies, in cultural life, the historical method, which began in the 19th century, became dominant (italics by Z. B.).

"Khamsa Melikdoms" (khamsa - Arabic word, means five, Melik - king, that is, the country of five melikdoms; we are talking about the five princes of Artsakh, who became famous for their activities in time), along with the historical material, also possesses artistic features, methodological elements, typical, vivid characteristics of images, rich chivalrous features, emphasized by the characteristic features of fine art, which give the book subtle psychological transitions, philosophical ideas, an abundance of literary genres that shine in their qualities (italics by Z. B.)

Raffi, following his great predecessors, tried both to create a bicentennial epic image of the Khamsa Melikdom and to save the history of the Artsakh melikdoms from oblivion.

In this case, the material should be studied by the method of semiotics as a semiotic literary critic and as a semiotic historian (italics by Z. B.). This method and methodology of analysis denote the scope of the method of semiology. We believe that Raffi in his book was guided (consciously or not consciously) by the semiotic method - presenting himself as the founder of a new direction (italics by Z. B.), and we, in the analysis of the "Khamsa Melikdoms" and general research.

In the article "History is the Mother of Truth", the famous Russian scientist D. J. Likhachev (1981) makes an important logical conclusion: regarding the style of a work of art, he considers meaningless those parts of the studied works that are "not covered by a deep historicism", (pp. 209-210) which, in turn, makes it possible to stay away from "extreme subjectivism" and not to abandon the possible "impressionistic" (impressionable) - (italics by Z. B.) literary studies".

Speaking about the criteria for evaluating a literary work, the author concludes his article as follows, highly appreciating the role of the historical approach: "The historical approach with all its provisions - from the history of the text, the history of life, the history of literature and general history to the history of the question - is the nerve of our science..." (Likhachev, 1981, p. 214).

In accordance with the principle of effective scientific work, in the respective comparative perception and observation, Yu. Lotman (1967) raises the question of a new type of literary critic, noting: "A new type of literary critic is a researcher who must combine independently acquired empirical material with deductive thinking developed by the exact sciences" (p. 100).

According to the content structure, Raffi created the "Khamsa Melikdoms" with two parallel methodologies and programming based on written sources and traditions. Many of the discovered written sources, being historical facts, also generalize epic fragments in their depth.

Raffi sought to present a historical fact that is also epic as a perfect reality, to try to define it, to find its "fulfilling role" (italics by Z. B.).

The author created a gallery of artistic and 
historical mythical images, methodically bringing it to a typed system in which typical characters are presented in typical circumstances and typical features.

Coordinating the images of the "Khamsa Melikdoms" according to the content structure, we can distinguish three directions: the first - natural-geographical, ethnic, related to the identification of the concept of Armenian studies, the cognitive orientation of the native country, the second - the study of the social structure, the third - the identification of the historical and historiographical description of the Khamsa melikdoms.

The two-month journey of the writer from Agwan around the world has borne fruit. Raffi recognized his native country, the melikdoms of Artsakh, with their centres, ruins and fortresses, and spiritual complexes. The chronicler, collecting materials from the memories of the ancient Melik palaces, from the Armenian temples, created the history of the Meliks of Khamsa.

Raffi also stated the virtue of the Artsakh people and the Meliks, tribal psychology, their confrontation to internal and external forces, truthfully presented Armenian-Russian, ArmenianGeorgian, Armenian-Persian relationships, and full of danger Armenian-European relations.

Fascinated by this preoccupation with the mission of collecting possible information about the melikdoms and turning it into history, Raffi writes a valuable book, "Khamsa Melikdoms", considering it a unit of Armenian literature (italics by Z. B.).

A representative of the late literary romanticism, Raffi, writing "Khamsa Melikdoms", also tried to reveal issues related to the social, moral, psychological, political, the national ideology of the Armenians of Artsakh and melikdoms, various issues related to the fate of the melikdoms in the region, expanding the ideas of the Meliks, bearing the progressive ideas of the era, about the high strata of thought of the Artsakh Armenians, about the political potential and sovereignty, the preservation of statehood.
Since in such literature the behaviour of the characters who have sought, but have not found, not only the romantic, but also the real world and its imaginative thinking, the demand for the artistic reference to the lessons of abandoned history, which oblige to be both a historical and an artistic nation, and since human virtues and emotional qualities are manifested in art, the description of the determinants fixed in the spirit of national and national, social existence, becomes mandatory. "It seems to me", writes Raffi, "this is the supreme controlling spirit, which itself exists in the unknown, which keeps it inaccessible, and with its powerful, invisible hand controls the hearts of people, the thoughts of people and directs them" (Raffi, 1959b, p. 18).

Trying to show the appeals of the national ideology in the "Khamsa Melikdoms", Raffi denotes the system that creates the image; in the images of the Meliks he shows the national spirit and then the manifestations of their confusion around the national ideology. Speaking about the concept of "national ideology", academician S. Sarinyan emphasizes the phenomenological feature of the idea, the manifestation of the spirit in aesthetics. "The national ideology is correlated with the national spirit" (Sarinyan, 2005, p. 4). From this point of view, Raffi indeed represents the philosophy of the Armenian people, the national spirit, the history and the literature of the Artsakh Armenians.

"The thinker and aesthetician Raffi", writes S. Sarinyan (2005), "took the Armenian liberation ideology to a new level, created its science, considering it not as a political worldview, but as nature, history, mythology, and biology ... the supreme creation" (p. 53).

Raffi is not just a statement of the truth. He understands the lessons of history, the philosophy of history well, but at the same time seeks to present historical facts from the perspective of educational and artistic methodology and colourful layers; to represent the characters, to give them an inner psychological tension, deep sensuality, lyrical movement. In the foreground, the 
author is the "natural" evidence of historical reality, in the second case, the discoverer of the spirit.

From this point of view, it is necessary to draw lessons both from the history and public life of Artsakh during the melikdoms, and from the present. The past and the present emphasize different pages of literature, public life, and the history of Artsakh, and are instructive for future generations, which is one of the important issues of the study (italics by Z. B.).

Hence the conclusion that the writer, representing the history of the Meliks of Artsakh of the XVIII-XIX centuries with its social, cultural, political, and social axes, notes very instructive aspects, shows the genetic qualities of the ancestral psychology of Artsakh and the people of Artsakh, freedom-loving spirit, military genius, and purposefulness.

An interesting epic passage is the military program put forward by Gayane, the daughter of the heroic radius of the Melik-Shahnazaryan family in Varand, Melik Huseyin, who crowned exceptional virtue, and all this connected with each other by the Artsakh throne, the secret popular uprising organized by Ishkhan Melik AvanYegan (1733) against Sara Mustafa Pasha. This was undoubtedly the revolt of the unity and the victory of the Meliks of Artsakh (italics by Z. B.).

The motherland here is absolute, indivisible, and it is the supreme organ and idea, which should be accepted as the only and highest contribution made by the fathers, as a biological spiritual gift: a spiritual council, a physical, historical, mythical, real and legal invincible, recognizable object (italics by Z. B.).

\section{Conclusion}

In parallel with the interpretation of Armenian and world philosophy, methodology, literary thought, poetics, methods of the XIX century, for the first time in the monograph "Artsakh in the Armenian literature of the XIX century", the topic of Artsakh in the general context of Armenian literature is put forward for examination and evaluation, which, in our opinion, will become one of the achievements of modern Armenian literary studies.

The XIX century in the history of the world philosophical, methodological, literary thought, the promotion of new methods can be called a revolutionary century.

It also led to a whole system of peculiar manifestations of the study of a literary work, associated with the identification of a re-evaluation based on the internal features of new philosophical and literary methods.

Our goal, which follows from the main provisions of the work, was to show (which, in our opinion, we succeeded in) the importance of the object under study, identifying in comparative and contrasted studies the methodology proposed by the researchers, their best practices, the novelty brought by literary methods, directions, demonstrating the visibility of those negative phenomena (based on the wrong choice of methods when considering literary works, fixing the facts of devaluation of authors and their works) that caused the denial of literary works.

Methodological research references to some of the works of Raffi and Muratsan, which are part of the study "Artsakh in the Armenian literature of the XIX century", were made against the background of the correct interpretation of the world philosophical and literary methods of the XIX century presented in the article, reaching the idea of their re-evaluation.

\section{References}

Bakhtin, M. (1963). Problemy poetiki Dostoevskogo (Problems of Dostoevsky's poetics, in Russian). Moscow: Soviet Writer.

Gaydenko, P. (2000). Istoriya novoevropeyskoi philosophii v eyo svyazi s naukoy (History of New-European Philosophy in its Connection with Science, in Russian). Moscow: Per Sei. 
Likhachev, D. (1981). Istoriya - mat' istiny (History - the mother of truth, in Russian). Leningrad: Soviet Writer.

Lotman, Yu. (1967). Literaturovedenie dolzhno byt' naukoi, Voprosy literatury (Literary criticism should be a science, in Russian). Voprosy literatury (Questions of Literature, in Russian), 1, 90-100. Retrieved from https://voplit.ru/article/literaturovedenie-dolzhno-byt-naukoj/.

Muratsan (1963). Erkeri zhoghovatsu 7 hatorov (Collection of works in 7 vols., in Armenian). Yerevan: Haypethrat.

Muratsan, (1954). Ruzany ev nra qnnadatoghnery ("Ruzan" and its critics, in Armenian). Collection of Works in 5 vols. Yerevan: Haypethrat.

Pordz (Arm.: “Tentative”). (1880). №5.

Raffi (1959a). Khamsai Melikutyunnery (Khamsa Melikdoms, in Armenian) Collection of works in ten volumes. (Vol. 10). Yerevan: Haypethrat.

Raffi (1959b). Vipagrut'yuny' rusahayeri mej (The novel-writing of Russian Armenians, in Armenian). Collection of works in ten volumes. (Vol. 10). Yerevan:
Haypethrat.

Sarinyan, S. (2005). Hay azgayin gaghaparabanut'yun (Armenian national ideology, in Armenian). Yerevan: Zangak-97.

Terteryan, A. (1913). Muratsany vorpes mtatsogh ev geghaget (Muratsan as a thinker and aesthetician, in Armenian). Shogher taregirq ("Sunrays" yearbook, in Armenian). Saint-Petersburg.

Terteryan, A. (2009). Muratsany vorpes mtatsogh ev geghaget (Muratsan as a thinker and aesthetician, in Armenian). In D. Mikayelya (Ed.), Qarozelov miabanut'yun ev mardasirut'yun (Arvesti Muratsanyan orery' Arcaxum) (Promoting Unity and Humanism (The days of Muratsans' art in Artsakh), in Armenian) (pp. 59-142). The Artsakh Writers' Union. Stepanakert: "VACHAGAN BAREPASHT" publishing house.

Ulubabyan, B. (1994). Artsakhi patmut'yuny' skzbic minchev mer orery' (The history of Artsakh from the beginning till nowadays, in Armenian). Yerevan: M. Varandean publishing house. 